\title{
Effects of Accounting Information System Adoption on the Financial Performance of Commercial Bank in Nigeria
}

Akanbi T. A* and Adewoye J. 0

Department of Management and Accounting, Ladoke Akintola University of Technology, Nigeria

\begin{abstract}
The contribution of commercial banks to peoples' daily activities is huge, so, it is germane to examine various innovations to which their services are been performance effectively with financial improvement. Therefore, This study evaluated the adoption of the Accounting Information Systems (AIS) among commercial banks in Nigeria and the adoption effects on their financial performance. The study was carried out in Lekki Peninsula Area of Lagos Sate, Nigeria. Three-quarter of commercial banks in Nigeria has a branch in this area. 16 commercial banks present in this area of study were examined with 80 respondents randomly selected from each bank. Questionnaires were administered to these respondents in order to know about AIS adoption and the level of adoption among these banks. Return on Capital Equity (ROCE), Return on Total Asset (ROTA), Net operating Profit (NOP) and Gross Profit Margin (GPM) data were sourced from financial reports within the recent 10 years post AIS adoption years (20072017) of the selected commercial banks. Cronbach's alpha test was used to measure the stability of measurement tool and also simple linear regression test was also used to test the impact of AIS on bank performance. The study found that commercial banks in Nigeria adopted and use AIS in providing their services to their customers and the level of usage is relatively high. The findings indicated that AIS adoption has a positive significant with all the performance indicators (ROCE, ROTA, GPM and NOP) with $\alpha<0.05$. Therefore, the study recommends that Central Bank of Nigeria should continue to provide support for AIS adoption by commercial banks in Nigeria, commercial banks should adopt more on AIS in order to achieve more in their performance and also they should provide a platform for regular training and development of staffs, in order to keep them abreast in AIS world.
\end{abstract}

Keywords: Accounting Information System (AIS); Financial performance; ROCE; ROTA; NOP; Gross profit margin

\section{Introduction}

Recently, the objectives of business organizations have shifted from the earlier times which were only working towards profit making and survival. Today, the objectives of business organizations and financial institutions are beyond profit making, but includes; gaining competitive advantage, sustainability, surviving turbulence environment, customer satisfaction and effective decision making. In achieving these objectives, Technology cannot be cut-out. One of the paramount technology systems in financial institutions is Accounting Information System (AIS). AIS contains a series of devices used to undertake a set of common business functions such as accounting, human resources management and stock management. The core nature of a comprehensive AIS is to computerize business process and most importantly, to produce data in real-time. The main benefits of an optimal use of AIS in an organization are: better adaptation to a changing environment, better management of arm's length transactions and a high degree of competitiveness.

Saira et al. [1] stated that Accounting Information Systems (AISs) are responsible for analyzing and monitoring the financial condition of companies, preparation of documents necessary for tax purposes, providing information to support the many other organizational functions such as production, marketing, human resource management, and strategic planning. Furthermore, Ferran and Salim [2] opined that, with the use of IT applications, stakeholder groups' expectations, as users of accounting information, have been changed to need access to more frequent and detailed accounting information and data, rather than periodical aggregated financial reports. AIS is an automated accounting information that relies on computer and accounting software to capture and process the accounting data in organisations [3]. These software systems vary from small accounting software systems, such as Myob and QuickBooks, to large accounting software systems that are integrated with enterprise-wide software, such as enterprise resource planning (ERP) systems including systems applications and products (SAP) that are being implemented, particularly by large organizations [4]. These offer opportunities for organizations to enhance their accounting cycle processes by providing accurate, useful and timely accounting information to decision makers within organizations and other external stakeholder groups [5].

According to Al-Zoubi [6], performance indicators can be a factor or a quantitative or a qualitative variable that provides a simple and reliable means to measure achievement, or to reveal the changes associated with the development intervention, or to help assess the performance of a development intervener. On the other hand, performance is defined to be: a scale of what has been accomplished from the work of an organization or a team or a person. When collecting the two previous words the term becomes: performance indicators which is defined as: a set of quantitative and qualitative measures used to track performance over time to infer the extent to which this indicator of performance meets the levels of performance agreed upon [6]. Consequently, many researchers have worked on performance measurement using different indicators based on financial and non-financial. Some researchers like Abdul Karim and Alawneh [7] measured financial performance using Return on assets "ROA", Return on Equity "ROE", and return on sales "ROS". Hamdan et al. [8] measured performance using Earning per

*Corresponding author: Taibat Adenike Akanbi, Department of Management and Accounting, Ladoke Akintola University of Technology, P.M.B 4000, Ogbomoso, Oyo State, Nigeria, E-mail: taakanbi@lautech.edu.ng

Received August 14, 2018; Accepted August 20, 2018; Published August 27, 2018

Citation: Akanbi TA, Adewoye JO (2018) Effects of Accounting Information System Adoption on the Financial Performance of Commercial Bank in Nigeria. J Account Mark 7: 289. doi: 10.4172/2168-9601.1000289

Copyright: @ 2018 Akanbi TA. This is an open-access article distributed under the terms of the Creative Commons Attribution License, which permits unrestricted use, distribution, and reproduction in any medium, provided the original author and source are credited. 
Share (EPS) and on return on assets (ROA).

Furthermore, literatures have established that, the successful implementation of the AIS and its effectiveness occurs when accountants choose to adopt and move from a manual AIS to a relatively more advanced and effective AIS $[9,10]$. This means that making the AIS available and accessible to accountants does not automatically imply that it will be adopted and used by them [9,11]. Aoun et al. [11] state that 'implementing AIS technologies do not necessary imply that firms will have better efficiency and effectiveness in accounting operations'. Does this stand? On the other hand, performance of financial institutions has been measured by Nigeria researchers using different indicators ranging from financial and non-financial. Nevertheless, there are few findings on AIS adoption and bank's financial performance using more than one performance indicators in Nigeria. However, there are 22 commercial banks in Nigeria and they are been instructed by the Central Bank of Nigeria, including their operational investment, thus, it is cogent to examine how adoption of AIS has been affecting Nigerian bank's performance. Moreover, this study will practically give answers to the following research questions:

Which AIS devices are been adopted by commercial bank in Nigeria?

What are the reasons for AIS adoption?

Does AIS adoption have any effects on Return on Capital Equity (ROCE) of the selected commercial bank?

Does AIS adoption have any effects on Return on Total Asset (ROTA) of the selected commercial bank?

Does AIS adoption have any effects on Net Profit Margin (NPM) of the selected commercial bank?

Does AIS adoption have any effects on Net Operating Asset (NOA) of the selected commercial bank?

\section{Theoretical Framework}

This research will examine some performance based models. These models include:

\section{Technology acceptance model}

Technology acceptance model (TAM) was originally proposed by Davies in 1986 [12]. This model was designed to forecast the user's acceptance of information technology and usage in an organizational setting. Cracknell [13] posits that firms are adopting technology to cope with the change in the external environment. This model has been tailored in a manner that can accommodate changes for improved costs reduction and efficiency. TAM deals with perceptions as opposed to real usage, the model suggest that users, the key factors that influence their decision on how, where and when they will use it [12].

The factors to consider are: Perceived usefulness (PU). According to Davis, it is the degree to which a person believes that using a particular system will lead to improved performance and Perceived ease-of-use (PEoU) is explained as the degree to which a person believes that using a particular system would results to improved productivity. In this study, perceived usefulness (PU) and Perceived ease-of-use (PEoU) will be assumed to be the reason for AIS adoption by Nigerian commercial banks.

\section{Diffusion of innovation theory}

Rogers [14] posits that diffusion of innovations is a theory that seeks to explain how, why, and at what rate new ideas and technology spread through cultures. Rogers [14] explains that critical factors that determine the adoption of an innovation at the general level are the following: relative advantage, compatibility, complexity, trialability and observability. Relative advantage refers to the degree to which an innovation is perceived as providing more benefits than its predecessor. It results in increased efficiency, economic benefits and enhanced status.

Previous research has concluded that relative advantage of an innovation is positively related to the rate of adoption. When a user perceives relative advantage or usefulness of a new technology over an old one, they tend to adopt it. In this study, the context of AIS adoption is assumed to be relative advantage among other factors. The advantage includes; cost, benefit, barriers and risk have been reason for AIS adoption.

\section{Resource based theory}

Barney [15] posits that the possession of strategic resources provides an organization with a golden opportunity to develop competitive advantages over its rivals. These competitive advantages in turn can help the organization enjoy strong profits. In reference to Wernerfelt (1984) a strategic resource is an asset that is valuable, rare, difficult to imitate, and no substitutable. A resource is valuable to the extent that it helps a firm create strategies that capitalize on opportunities and ward off threats.

The supporters of this theory: Stern \& Stalk [16] argue that the firm is assumed to consist of internal and external coalition which emanate from the social exchanges that are formed to enhance and control behaviour. The external environment is assumed to consist of scarce and valued resources that are key for organizational survival. This is because of the uncertainty involved in the external environment in resource acquisition.

The relevance of this theory is that the banking environment is dynamic; it is characterized by risks and uncertainties due to changes in the external environment. This necessitates the need for adopting strategies to counter challenges in the external environment. According to Ortega (2010), organizations aim to achieve two key objectives namely: control over resources in order to reduce dependence on other firms and gain control over resources that enhance dependence of other firms on themselves (Figure 1).

\section{Methodology}

This study was carried out in Lekki Peninsula in Lagos Island, Lagos State, Nigeria. There are Sixteen (16) commercial banks in this Island, these banks are: Access bank, Diamond bank, Eco bank, FCMB, Fidelity Bank, First Bank, GTB, Keystone, Skye bank, Stanbic Bank, Sterling Bank, UBA, Unity Bank, Union Bank, Wema Bank and Zenith Bank. The choice of this Area is because of the high concentrations of both commercials and residential conglomerate in the Island. The researcher believes that with this magnitude, innovations in banking sector cannot be found wanting among commercial banks in this area of study. 5 staff was randomly selected from each selected banks, making a total of 80 respondents. Survey method was used to gathered primary data, questions were asked about the adoption of AIS and the type of AIS the banks adopted. Secondary data, which includes financial statement, were obtained from Websites of each bank within 


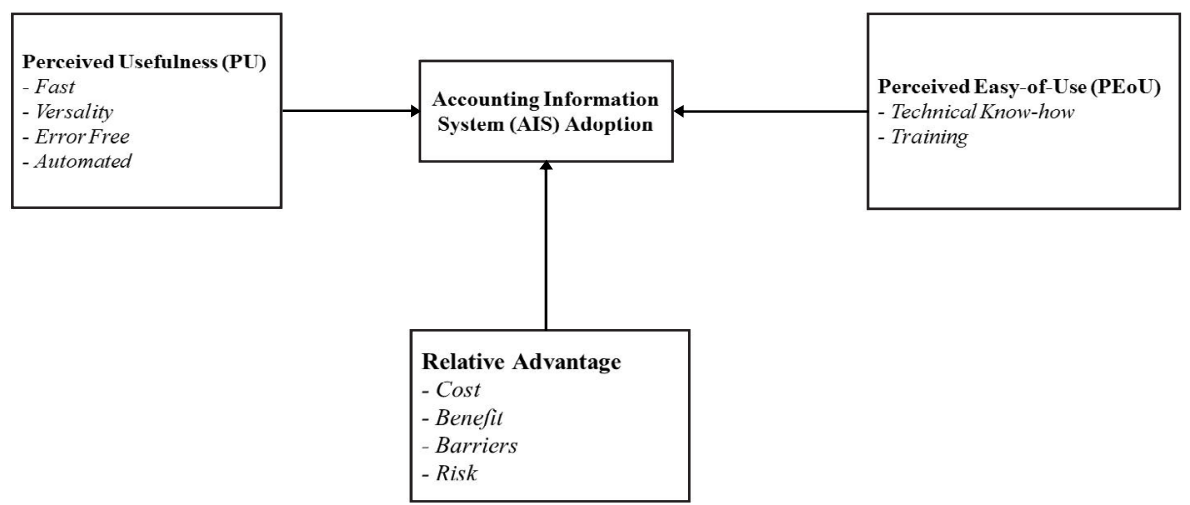

Source: Author's Compilation (2018)

Figure 1: Research Model (AIS adoption)

the study area. Return on Capital Equity (ROCE), Return on Total Asset (ROTA), Net operating Profit (NOP) and Gross Profit Margin (GPM) data were sourced from financial reports within the recent 10 years post AIS adoption years (2007-2017) of the selected commercial banks. Linear Regression was employed to test the significant Effect of AIS adoption on bank performance. In order to determine the Effect of AIS adoption on the performance of the banks, some variables were set, which are defined as follows:

\section{Dependent variable}

It is financial performance i.e. profitability of the selected commercial banks, were measured as:

Return on Capital Employed $\left(\right.$ ROCE) $=\frac{\text { Net Profit }}{\text { Capital Employee }} \times \frac{100}{1}$

Return on Total Asset $($ ROTA $)=\frac{\text { Profit before tax }}{\text { Total assets }} \times \frac{100}{1}$

Net Operating Profit $($ NOP $)=\frac{\text { Net Profit }}{\text { Net Sale }} \times \frac{100}{1}$

Gross Profit Margin $=\frac{\text { Gross profit }}{\text { Sales }} \times 100$

\section{Independent variable}

They are AIS adopted by the selected commercial banks which includes: Computer system, Finacle version 1, Finacle version 3, Equinox and Peach tree.

The regression model to be adopted in this study is as follows:

$\mathrm{Y}=\beta_{0}+\beta_{1} \mathrm{X}_{1}+\beta_{2} \mathrm{X}_{2}+\beta_{3} \mathrm{X}_{3}+\beta_{4} \mathrm{X}_{4}+\varepsilon$

Where

$\beta_{1}-\beta_{5}$, are the regression coefficients

$\mathrm{Y}=$ financial performance which was measured return on Gross profit ROCE margin, ROTA, NOP and
$\mathrm{X}_{1}$ represents use of computer system
$\mathrm{X}_{2}$ represents use of Finacle version 1
$\mathrm{X}_{3}$ represents the use of Finacle version 3
$\mathrm{X}_{4}$ represents the use of Equinox

$\mathrm{X}_{5}$ represents the use of Peach tree

$\beta_{0}=$ gradient or slope of the regression measuring the unit of change in $\mathrm{y}$ associated with a unit change in $\mathrm{X}$

$\varepsilon=$ Error term

\section{Cronbach's alpha test}

In this study reliability test was carried out on the final questionnaire administered to the respondents (Table 1).

80 questionnaires administered were returned and filled correctly. So this analysis was based on 80 questionnaires which indicate a response rate of $100 \%$. Test of reliability carried out on the final data gives a Cronbach's Alpha with a coefficient value of 0.899 . The 0.899 Cronbach's Alpha is higher than the 0.70 threshold for internal consistency. Therefore, the questionnaire instrument has an overall reliability.

\section{Findings and Discussion}

It is paramount for this study to make a finding on the adoption of AIS by the sampled banks. Table 2 below presented the result on the adoption of AIS by the sampled banks. It was revealed based on the opinion of the respondents (100\%) that all the sampled banks adopted AIS in their operation.

\section{Types of AIS adopted}

Table 3 revealed the type of AIS devices that are adopted by the sampled banks. This also in correlation with Table 1, as all the banks indicated that they adopted AIS. It was revealed that all the banks are making use of the following AIS devices in their daily operations:

\begin{tabular}{|c|c|}
\hline Cronbach's Alpha & No. of items \\
\hline .899 & 80 \\
\hline
\end{tabular}

Source: SPSS Output, 2018.

Table 1: Reliability statistics on final questionnaire.

\begin{tabular}{|c|c|c|}
\hline AIS adoption & Frequency & Percentage \\
\hline Yes & 80 & 100.0 \\
\hline No & - & - \\
\hline Total & 80 & 100.0 \\
\hline
\end{tabular}

Source: Field survey, 2018.

Table 2: Accounting Information System (AIS) adoption by the respondents. 
Computer system, Finacle version 1, Finacle version 3, Equinox and peach tree.

\section{Level of AIS usage}

The level of AIS usage was indicated on Table 4 below. The indicators are low, relatively high and high. It was revealed that AIS devices such as computer system, and finacle version 3 were highly in use by the sampled banks. Others such as fiancle version 1 and peach tree were relatives adopted. However, only equinox software was least in AIS usage as indicated by the finding. This corroborate with the findings of Fagbemi et al. [17,18].

\section{Reason for AIS adoption}

Theories of the research were tested in Table 5 below. Every innovations adoption must have their reasons. The reason behind AIS adoption was revealed in this study. From Tab, the table was divided into categories which are PU, PEoU and relative advantage.

\begin{tabular}{|c|c|c|c|}
\hline Type & Yes (\%) & No(\%) & Total (\%) \\
\hline Computer system & $80(100.0)$ & - & $80(100.0)$ \\
\hline Finacle version 1 & $80(100.0)$ & - & $80(100.0)$ \\
\hline Finacle version 3 & $80(100.0)$ & - & $80(100.0)$ \\
\hline Equinox & $80(100.0)$ & - & $80(100.0)$ \\
\hline Peach tree & $80(100.0)$ & - & $80(100.0)$ \\
\hline
\end{tabular}

Source: Field survey, 2018

Table 3: Types of AIS adopted

\begin{tabular}{|c|c|c|c|}
\hline Level & Low & Relative high & High \\
\hline Computer system & & - & $80(100)$ \\
\hline Finacle version 1 & - & $80(100)$ & - \\
\hline Finacle version 3 & - & - & $80(100)$ \\
\hline Equinox & $80(100)$ & - & - \\
\hline Peach tree & - & $80(100)$ & - \\
\hline
\end{tabular}

Source: Field survey, 2018.

Table 4: Level of AIS usage.
For PU, it was discovered that majority of the respondent $80 \%$ were strongly agreed that AIS is very fast in computing transactions compare to manual-method and $88 \%$ as well agreed that using AIS minimize errors and mistakes. The highly impacted reasons (with $100 \%$ agreement by the respondents) are that: AIS can be used for many things at a time, such as taking input, sending mails, live chatting, etc; AIS software are tailor made, which are made to undergo automated job; using AIS reduces stress on job delivery and AIS improves the quality of the work done. Furthermore, on the categories of PEOU, it was discovered (by all of the respondent) that some of the staff prefer AIS because of some reasons which are: they don't become confused when using AIS, interacting with AIS requires little mental efforts, it is very easy to remember how to perform task using AIS, AIS is not cumbersome to use and that AIS provides helpful guidance in performing task. Other factors is that learning and using AIS is not complicated as agreed by $66 \%$ of the respondents and training cost is also bearable it learning required. The final categories is the relative advantage, according to all of the respondents (100\%) sampled, it was discovered that acquiring AIS is less costly compare to it usage and AIS perform various functions that aid operations. Thus, $70 \%$ of the respondents agreed that acquisition of AIS is achievable with no policy implications while $14 \%$ are undecided. However, this result is in line with the findings of Cracknell [13] on Technology Acceptance Model and Rogers [14] on Diffusion of Innovation Theory.

\section{Effect of AIS usage on Return on Capital Equity (ROCE)}

The analyses revealed (Table 6) that Accounting Information System (AIS) adoption has a positive and significant effects on ROCE. The coefficient of determination $\mathrm{R}^{2}$ is 0.801 , which means that $80.1 \%$ of the variability in ROCE (dependent variable) was influenced by the adoption of Computer system, Finacle software, equinox and Peachtree software (independent variable). Hence, $19.9 \%$ variability in ROCE was explained by other factors outside AIS adoption. The f-statistics of 9.74 shows overall significance of

\begin{tabular}{|c|c|c|c|c|c|c|}
\hline $\mathbf{S} / \mathbf{N}$ & Reasons & SA(\%) & $\mathbf{A}(\%)$ & $U(\%)$ & $\mathrm{D}(\%)$ & $\mathrm{SD}(\%)$ \\
\hline & \multicolumn{6}{|l|}{ Perceived Usefulness (PU) } \\
\hline 1 & AIS is very fast in computing transactions compare to manual-method & $64(80)$ & $16(20)$ & - & - & - \\
\hline 2 & $\begin{array}{l}\text { AIS can be used for many things at a time, such as taking input, sending mails, live chatting, } \\
\text { etc }\end{array}$ & $80(100)$ & - & - & - & - \\
\hline 3 & Using AIS minimize errors and mistakes & $70(88)$ & $10(12)$ & - & - & - \\
\hline \multirow[t]{2}{*}{4} & AIS software are tailor made, which are made to undergo automated job. & $80(100)$ & - & - & - & - \\
\hline & Using AIS reduces stress on job delivery & $80(100)$ & - & - & - & - \\
\hline \multirow[t]{2}{*}{5} & AIS improves the quality of the work done & $80(100)$ & - & - & - & - \\
\hline & \multicolumn{6}{|l|}{ Perceived Easy-of-Use (PEoU) } \\
\hline 6 & Learning and using AIS is not complicated & $25(34)$ & $55(66)$ & - & - & - \\
\hline 7 & Training cost of AIS is bearable & - & $80(100)$ & - & - & - \\
\hline 8 & You don't become confused when using AIS & $80(100)$ & - & - & - & - \\
\hline 9 & Interacting with AIS requires little mental efforts & $80(100)$ & - & - & - & - \\
\hline 10 & It is very easy to remember how to perform task using AIS & $80(100)$ & - & - & - & - \\
\hline 11 & AIS is not cumbersome to use & $80(100)$ & - & - & - & - \\
\hline \multirow[t]{2}{*}{12} & AIS provides helpful guidance in performing task & $80(100)$ & - & - & - & - \\
\hline & \multicolumn{6}{|l|}{ Relative Advantage } \\
\hline 13 & Acquiring AIS is less costly compare to it usage & $80(100)$ & - & - & - & - \\
\hline 14 & AIS perform various functions that aid operations & $80(100)$ & - & - & - & - \\
\hline 15 & Acquisition of AIS is achievable with no policy implications & $7(10)$ & $61(76)$ & 11(14) & - & - \\
\hline
\end{tabular}

Source: Field survey, 2018. 
Citation: Akanbi TA, Adewoye JO (2018) Effects of Accounting Information System Adoption on the Financial Performance of Commercial Bank in Nigeria. J Account Mark 7: 289. doi: 10.4172/2168-9601.1000289

the regression model. F-sig. level of .0001 is less than 0.05 which suggests that Accounting Information System (AIS) adoption has a positive and significant impact on ROCE. Therefore, the level of AIS adoption can influences bank performance in terms of ROCE and this corroborates with the research of Ironkwe et al. [19] and Augustine et al. [20].

\section{Effect of AIS adoption on Return on Total Asset (ROTA)}

The analyses revealed (Table 7) that Accounting Information System (AIS) adoption has a positive and significant effects on ROTA. The coefficient of determination $\mathrm{R}^{2}$ is 0.831 , which means that $83.1 \%$ of the variability in ROTA (dependent variable) was influenced by the adoption of Computer system, Finacle software, equinox and Peachtree software (independent variable). Hence, $16.9 \%$ variability in ROTA was explained by other factors outside AIS adoption. The f-statistics of 9.23 shows overall significance of the regression model. F-sig. level of .0000 is less than 0.05 which suggests that Accounting Information System (AIS) adoption has a positive and significant impact on ROTA. Therefore, the level of AIS adoption can influences bank performance in terms of ROTA and this as well corroborates with the findings of Ironkwe et al. [19].

\section{Effect of AIS adoption on Gross Profit Margin (GPM)}

The analyses revealed (Table 8) that Accounting Information System (AIS) adoption has a positive and significant effects on GPM. The coefficient of determination $\mathrm{R}^{2}$ is 0.806 , which means that $80.6 \%$ of the variability in GPM (dependent variable) was influenced by the adoption of Computer system, Finacle software, equinox and Peachtree software (independent variable). Hence, $19.4 \%$ variability in GPM was explained by other factors outside AIS adoption. The f-statistics of 8.23 shows overall significance of the regression model. F-sig. level of .0000 is less than 0.05 which suggests that Accounting Information System (AIS) adoption has a positive and significant impact on GPM. Therefore, the level of AIS adoption can influences bank performance in terms of GPM. This finding is in line with the findings of Ali et al.

\begin{tabular}{|c|c|c|c|c|c|}
\hline \multicolumn{7}{|c|}{ Model Coefficients $^{\mathbf{a}}$} \\
\hline \multirow{2}{*}{ Model } & $\begin{array}{c}\text { Unstandardized } \\
\text { Coefficients }\end{array}$ & $\begin{array}{c}\text { Standardized } \\
\text { Coefficients }\end{array}$ & \multirow{2}{*}{$\mathrm{t}$} & \multirow{2}{*}{ Sig. } \\
\cline { 2 - 6 } & $\mathrm{B}$ & Std. Error & Beta & & \\
\hline (Constant) & 49.370 & 109.055 & & .453 & .002 \\
\hline $\begin{array}{c}\text { Computer } \\
\text { System }\end{array}$ & 60.000 & 54.280 & .210 & 1.105 & .000 \\
\hline Finacle1 & 21.315 & 44.622 & .026 & .231 & .000 \\
\hline Finacle3 & 43.315 & 31.765 & .036 & .325 & .000 \\
\hline Equinox & 34.315 & 46.023 & .026 & .231 & .818 \\
\hline Peachtree & 19.685 & 32.372 & .084 & .441 & .012 \\
\hline
\end{tabular}

\section{Model Summary}

$\mathrm{R}$

\begin{tabular}{|lll|}
\hline R & - & $895^{\mathrm{a}}$ \\
\hline R Square & - & .801 \\
\hline Adjusted R Square & - & .718 \\
\hline Std. Error of the Estimate & - & .5935 \\
F-Statistics & - & 9.749 \\
Prob (F-Statistics) & - & 0.001 \\
\hline
\end{tabular}

Source: Field Survey, 2018.

Note: a: Dependent Variable (Constant): ROCE.

Table 6: Regression analysis Results I.

\section{Effect of AIS adoption on Net Operating Profit (NOP)}

The analyses revealed (Table 9) that Accounting Information System (AIS) adoption has a positive and significant effects on NOP. The coefficient of determination $\mathrm{R}^{2}$ is 0.764 , which means that $76.4 \%$ of the variability in NOP (dependent variable) was influenced by the adoption of Computer system, Finacle software, equinox and Peachtree software (independent variable). Hence, $33.6 \%$ variability in NOP was explained by other factors outside AIS adoption. The f-statistics of 9.42 shows overall significance of the regression model. F-sig. level of .0000 is less than 0.05 which suggests that Accounting Information System (AIS) adoption has a positive and significant impact on NOP. Therefore, the level of AIS adoption can influences bank performance in terms of NOP. This result is in line with the findings Ironkwe [19], Augustine M et al. [20].

\begin{tabular}{|c|c|c|c|c|c|}
\hline \multicolumn{6}{|c|}{ Model Coefficients ${ }^{a}$} \\
\hline \multirow[t]{2}{*}{ Model } & \multicolumn{2}{|c|}{$\begin{array}{l}\text { Unstandardized Coef- } \\
\text { ficients }\end{array}$} & \multirow{2}{*}{$\begin{array}{c}\text { Standardized } \\
\text { Coefficients } \\
\text { Beta }\end{array}$} & \multirow[t]{2}{*}{$\mathbf{t}$} & \multirow[t]{2}{*}{ Sig. } \\
\hline & B & Std. Error & & & \\
\hline (Constant) & 32.493 & 37.668 & & .863 & .000 \\
\hline $\begin{array}{l}\text { Computer- } \\
\text { System }\end{array}$ & 45.234 & 18.749 & .000 & .000 & .000 \\
\hline Finacle1 & 34.112 & 15.413 & .047 & .405 & .000 \\
\hline Finacle3 & 14.023 & 10.972 & .066 & .569 & .000 \\
\hline Equinox & 23.342 & 15.342 & .047 & .405 & .686 \\
\hline Peachtree & 34.23 & 15.413 & .080 & .342 & .000 \\
\hline \multicolumn{6}{|c|}{ Model Summary } \\
\hline \multicolumn{2}{|l|}{$\mathrm{R}$} & \multicolumn{4}{|l|}{$912^{\mathrm{a}}$} \\
\hline \multicolumn{2}{|l|}{ R Square } & \multicolumn{4}{|l|}{.831} \\
\hline \multicolumn{2}{|c|}{ Adjusted R Square } & \multicolumn{4}{|l|}{.748} \\
\hline \multirow{3}{*}{\multicolumn{2}{|c|}{$\begin{array}{l}\text { Std. Error of the Estimate } \\
\text { F-Statistics } \\
\text { Prob (F-Statistics) }\end{array}$}} & \multicolumn{4}{|l|}{.55224} \\
\hline & & \multicolumn{4}{|l|}{9.231} \\
\hline & & \multicolumn{4}{|l|}{0.000} \\
\hline
\end{tabular}

Note: a: Dependent Variable (Constant): ROTA Source: Field Survey, 2018.

Table 7: Regression analysis Results II.

\begin{tabular}{|c|c|c|c|c|c|}
\hline \multicolumn{6}{|c|}{ Model Coefficients ${ }^{a}$} \\
\hline \multirow[t]{2}{*}{ Model } & \multicolumn{2}{|c|}{$\begin{array}{l}\text { Unstandardized } \\
\text { Coefficients }\end{array}$} & \multirow{2}{*}{$\begin{array}{c}\text { Standardized } \\
\text { Coefficients } \\
\text { Beta }\end{array}$} & \multirow[t]{2}{*}{$\mathbf{t}$} & \multirow[t]{2}{*}{ Sig. } \\
\hline & B & Std. Error & & & \\
\hline (Constant) & 51.086 & 20.474 & & 2.495 & .001 \\
\hline ComputerSystem & 1.325 & 3.737 & .039 & .355 & .000 \\
\hline Finacle1 & 11.740 & 4.190 & .311 & 2.802 & .006 \\
\hline Finacle3 & 8.164 & 5.188 & .171 & 1.574 & .002 \\
\hline Equinox & 16.628 & 9.190 & .195 & 1.809 & .074 \\
\hline Peachtree & 13.037 & 9.806 & .153 & 1.330 & .000 \\
\hline \multicolumn{6}{|c|}{ Model Summary } \\
\hline \multicolumn{2}{|l|}{$\mathrm{R}$} & \multicolumn{2}{|c|}{$.898^{\mathrm{a}}$} & & \\
\hline \multicolumn{2}{|l|}{ R Square } & \multicolumn{2}{|l|}{.806} & & \\
\hline \multicolumn{2}{|l|}{ Adjusted R Square } & \multicolumn{2}{|l|}{.723} & & \\
\hline \multirow{2}{*}{\multicolumn{2}{|c|}{$\begin{array}{l}\text { Std. Error of the Estimate } \\
\text { F-Statistics }\end{array}$}} & \multirow{2}{*}{\multicolumn{2}{|c|}{$\begin{array}{l}.53245 \\
8.231\end{array}$}} & & \\
\hline & & & & & \\
\hline \multicolumn{2}{|l|}{ Prob(F-Statistics) } & 0.000 & & & \\
\hline
\end{tabular}

Note: a: Dependent Variable (Constant): Gross Profit Margin. Source: Field Survey, 2018.

Table 8: Regression analysis Results III. 
Citation: Akanbi TA, Adewoye JO (2018) Effects of Accounting Information System Adoption on the Financial Performance of Commercial Bank in Nigeria. J Account Mark 7: 289. doi: 10.4172/2168-9601.1000289

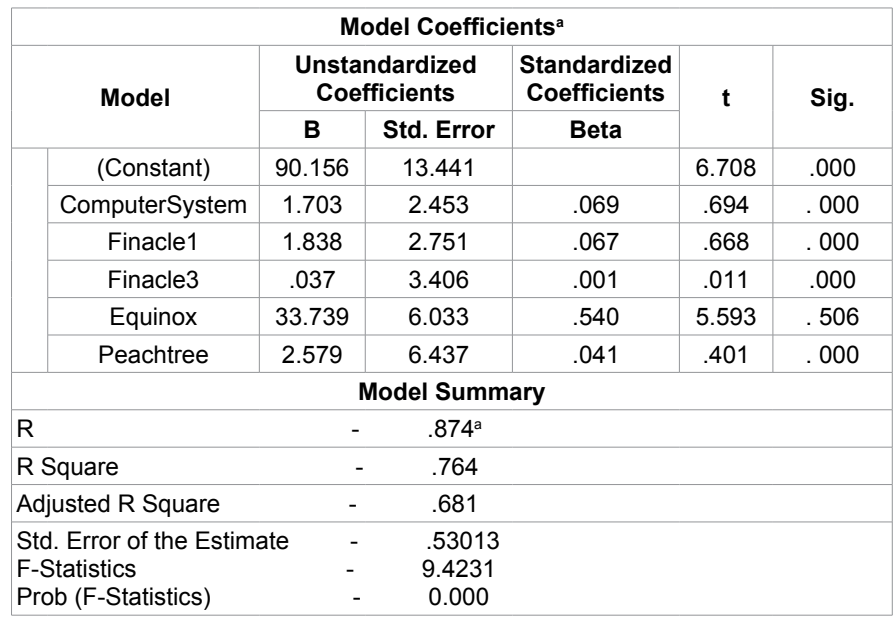

Note: a: Dependent Variable (Constant): NOP.

Source: Field Survey, 2018.

Table 9: Regression analysis Results IV.

\section{Conclusion and Recommendations}

From the findings of this study, conclusions were drawn that:

- Commercial banks in Nigeria make use of AIS in their operation and this AIS devices and software includes: computer system, Finacle version 1, Finacle version 3, Equinox, and Peach tree while the level of usage is relatively high. This finding supported the research of Harsh [21].

- The reasons behind adoption of AIS are their perceived usefulness (PU), perceived easy-to-use (PEoU) and the relative advantages of AIS in fast-tracking banking operation. It corroborates the findings of Ironkwe et al. [19].

- There is a statistical (with $a<0.05$ ) effects of AIS adoption on Return on Capital Equity (ROCE) which means that using AIS can influence organization's ROCE. It collaborate the findings of Fagbemi et al. [17].

- Likewise, there is a statistical (with $a<0.05$ ) effects of AIS adoption on Return on Total Asset (ROTA) which means that using AIS can influence organization's ROTA. It corroborates the findings of Ironkwe et al. [19].

- Also, there is a statistical (with $\alpha<0.05$ ) effects of AIS adoption on Gross Profit Margin (GPM) which means that using AIS can influence organization's GP. It corroborates the findings of Ali et al.

- There is a statistical (with $\alpha<0.05$ ) effects of AIS adoption on Net Operating Asset (NOP) which means that using AIS can influence organization's NOP. It corroborates the findings of Lallo et al.

- In General, AIS adoption and usage influence bank performance. This corroborated with the findings of AbdulKarim et al. [7].

\section{The following recommendations were made:}

- As the important of Accounting Information System (AIS) on banks' performance is been revealed, commercial bank should adopt more on AIS in order to achieve more in their performance.
- Government, especially CBN should continue to provide support for AIS adoption by commercial banks in Nigeria.

- Commercial banks should provide a platform for regular training and development of staffs, in order to keep them abreast in AIS world.

\section{References}

1. Saira K, Zariyawati MA, Annuar MN (2010) Information system and firms performance: The Case of Malaysian small medium enterprises. Int Bus Res 3: 28-35.

2. Ferran C, Salim R (2011) IAC accounting data model: a better data structure for computerized accounting systems. Rev Bus Info Syst 8: 109-120.

3. Stefanou CJ, Marilena AT (2006) The complexity and the research area of AIS J Enterp Info Manage 19: 9-12.

4. Sutton SG (2005) The role of AIS research in guiding practice. Int J Account Info Sys 6: 1-4.

5. Moorthy MK, Seetharaman A, Gopalan M, San LH (2010) The necessities of paperless accounting system. Am J Sci Res 7: 106-18.

6. Zoubi AM (2017) The Extent of Electronic Accounting Information Systems Ability to Provide Quantitative Indicators of Financial Performance in both Public and Private Universities in Jordan. Int $\mathrm{J}$ Acad Res Account. Finance Manage Sci 7: 97-107.

7. Karim AN, Alawneh S (2009) The impact of investment in information technology on the financial performance of Corporation companies listed on the market Palestine, Najah University. J Res Humanit 23: 989-1028.

8. Hamdan AM, Anasoh MS, Otaibi MH (2012) The impact of the ownership structure in the level of investment in information technology and its impact on the performance of the Jordanian banks: an analytical study of the period 20032008. J Islamic Univ Eco Stud Manage 20: 381-416.

9. Dowling M, Helm R (2009) Product development success through cooperation: A study of entrepreneurial firms. Technovation 26: 483-488.

10. Yilmaz E, Özer G (2008) Information technology usage of accountants. The First Int Confer Manage Eco pp: 318-333.

11. Aoun C, Vatanasakdakul S, Li Y (2010) AIS in Australia: UTAUT application \& cultural implication. ACIS 2010 Proceedings Paper pp: 1-12.

12. Davis FD (1989) Perceived Usefulness, Perceived Ease of Use, and User Acceptance of Information Technology. MIS Quarterly 13: 319-340.

13. Cracknell D (2004) Electronic Banking for the poor: Panacea, Potential and pitfalls. Practical Action Publishing 15

14. Rogers EM (1962) Diffusion of Innovations. (4th edn), NY: Free Press, New York.

15. Barney J (1991) Firm resources and sustained competitive advantage. J Manage 17: 99-120.

16. Stern CW, Stalk G (2001) Perspectives on Strategy from the Boston Consulting Group. ( $2^{\text {nd }}$ edn), John \& Wiley \& Sons, Massachusetts, Boston.

17. Fagbemi TO, Olaoye JA (2016) An Evaluation Of Accounting Information System And Performance Of Small Scale Enterprises In Kwara State, Nigeria. DBA Africa Manage Rev 6: 1-16.

18. Grande UE, Estebanez PR, Colomina MC (2010) The impact of accounting information on performance measures: empirical evidence in Spanish SMEs. The Int J Digit Account Res 11: 25-43.

19. Ironkwe UI, Otti JO (2016) Accounting Information and Financial Performance of Banks in Nigeria. J Account Financ Manage 2: 1-9.

20. Augustine M, Maurine K, Jian Z (2014) Impact of Accounting Information Systems on Profitability of Small Scale Businesses: A Case of Kampala City in Uganda. Int J Acad Res Manage 3: 185-192.

21. Harash E (2017) Accounting Performance of SMEs and Effect of Accounting Information System: A Conceptual Model. Glob J Manage Bus Res: Account Audit 17: 1-7. 